\title{
SECURING THE SAFETY OF HERITAGE BUILDINGS IN ACTIVE SEISMIC REGIONS
}

\author{
M. DANIELI \\ Department of Civil Engineering, Ariel University, Israel.
}

\begin{abstract}
This article describes the principles and actual procedures of restoration and strengthening of heritage buildings that have been applied in mountainous regions of Caucasus, in Georgia. The buildings in question are the 11th century temple in Nikortsminda and the 19th century synagogue in Oni, both damaged by an earthquake in 1991. This article presents examples of conservation of these two structures and refers to a conservation project for the 18th century mosque in Akhaltsikhe. As to the Nikortsminda temple, temporary conservation was applied prior to an expected aftershock period. Its permanent conservation was completed 2 years later. In all three cases, the design was aimed at preservation of initial geometry and appearance by creating composite (stone-reinforced concrete) structures, which were partially or fully hidden. It is worth mentioning that both the temple in Nikortsminda and the synagogue in Oni survived the Richter magnitude 6.2 earthquake in this region on September 8, 2009, without any substantial damage caused. The causes of deformation and loss of stability of thin shallow shell of the same type are analyzed; the example of strengthening and safeguarding the shell of this type is given. The method used for the shell strengthening was assumed as a basis for developing the method of strengthening ancient stone domes. The authors believe that design principles applied in these projects can provide substantial contribution to successful conservation of much larger projects, along with the increase in their earthquake resistance.

Keywords: damaged, heritage buildings, limit analysis, seismic regions, shallow shell, strengthening.
\end{abstract}

\section{INTRODUCTION}

Many heritage buildings as a structural and architectural element have utilitarian value. Numerous ancient buildings, although not as large as the Pantheon or the Hagia Sophia, can also be of certain value in the historical, architectural, and engineering aspects. The evaluation of a building in these aspects predetermines the significance of its preservation. In addition, a possibility of its utilization is to be considered.

Built many centuries ago, the heritage buildings often need restoration and strengthening, especially in seismic regions. Preserving architectural-historical monuments in their original state is one of the responsibilities of a civilized society. At the end of the 19th century, the new material, the reinforced concrete, having good compression, and tension resistance capacity began to oust stone constructions. It must be noted that concrete retains its properties for a long period of time; for example, the dome of the Pantheon of Rome was constructed of concrete 2000 years ago [1]. For the strengthening or conservation of Historic Heritage buildings, both traditional and modern methods and principles can be used [2-8]. International conferences on seismic resistance of structures devote special sections to this problem; it may also be the subject for debate at special international conferences [9] and other. Their studies and summaries are important.

Today, there are many research projects concerning conservation and restoration of masonry domes, vaults, and arch structures in the seismic regions, and several technologies are used for their strengthening: metal strengthening rings $[4,6,10]$, straining beams $[5,11$, 12], doubling structures [3], carbon fiber cords [13], reinforcement systems consisting of carbon fiber tapes and epoxy raisins (carbon structural reinforcement system) $[8,14]$, masonry 
injection using cement or a polymer solution [15], polymer grids [16], concrete spraying [6, 17,18], reinforced concrete jackets [2], and reinforced concrete; one- or two-sided thin coatings [3] are traditionally applied. Non-traditional components, innovative methods, and materials are also applied [2]. All methods of strengthening mentioned above have advantages and disadvantages. Successful application of these methods depends on several factors: importance of the historical monument, its engineering state, safety demands, possible level of technology to fulfill these jobs on the exact site, special considerations of engineers, owners of monuments, and so on. Besides, successfully providing the security of structures is helped by the long-term monitoring of the structures before and after the works on strengthening [14], studying and testing of the materials used for strengthening, large-scale model experimental research $[8,19,20]$, computer simulations, and analysis using finite element method (FEM) [21,22], including due account of the non-linear properties of the materials, as well as by an estimation of the load-bearing capacity of the structures [21] in accordance with the limit analysis theory [23-25] and so on. Using reinforced concrete provides wide possibilities in strengthening historic buildings; including stone domes, as reinforced concrete is a material well compatible with stone masonry. At the same time, in many cases, the use of reinforced concrete for strengthening constructions for conservation enables creating almost invisible elements in order not to distort the look of the monument.

This article deals with the examples of restoration and strengthening of three heritage buildings in Georgia, two of which were damaged by an earthquake on April 30, 1991 (a temple in Nikortzminda and a synagogue in Oni built in the 11th and 19th centuries, respectively) and an architectural-historical monument (former mosque) in Akhaltsikhe (conservation project) built in the 18th century. A temple in Nikortzminda and the building of the synagogue in Oni are located in an active seismic zone in North Georgia. The building of the former mosque in the town of Akhaltsikhe is located in South Georgia. Causes of deformation and loss of stability of thin shallow shell of the same type are analyzed; the example of strengthening and safeguarding the shell of this type is given. The method used for the shell strengthening was assumed as a basis for developing the method of strengthening ancient stone domes.

\section{SEISMIC SITUATION OF THE BUILDINGS LOCATION}

On April 29, 1991, there was an earthquake in northern Georgia. Magnitude of the earthquake in Racha, Georgia, on April 29, 1991, by Richter scale according to the accepted estimations was Ms $=6.9$ [26]. This magnitude corresponds to the intensity of $\mathrm{I}_{0}=9.5$ on the MSK-64 12-step scale. Over 46 thousand buildings were damaged or destroyed. Several thousands of aftershocks were registered later on, during four months. Their magnitudes varied between $M$ $=6.2$ and 5.3, being sometimes almost as powerful as the primary shock. The following chart (Fig. 1) illustrates this situation [6].

A temple in Nikortzminda: the distance to the earthquake epicenter was about $45 \mathrm{~km}$. The estimated intensity of the primary shock was 7 on the seismic scale MSK-64 ( $\mathrm{a}=0.5 \div 1.0$ $\mathrm{m} / \mathrm{sec}^{2}$ at the foundation). The synagogue in Oni: the distance to the earthquake epicenter was $25 \div 30 \mathrm{~km}$. The measured intensity was a $=2 \mathrm{~m} / \mathrm{sec}^{2}$.

The building in Akhaltsikhe: the expected Richter magnitude for the Akhaltsikhe area is $M=7$. The mosque in Akhaltsikhe, built in the 18th century in South Georgia, was damaged by a series of major earthquakes: (a) in Akhalkalaki, Georgia, in 1899, at the distance of 45 $\mathrm{km}, \mathrm{M}=5.4$; (b) in Spitak, Armenia, in 1988, at $125 \mathrm{~km}, \mathrm{M}=6.9$; and (c) in Racha, Georgia, on April 29, 1991, at $125 \mathrm{~km}, \mathrm{M}=6.9$ [26]. 
A

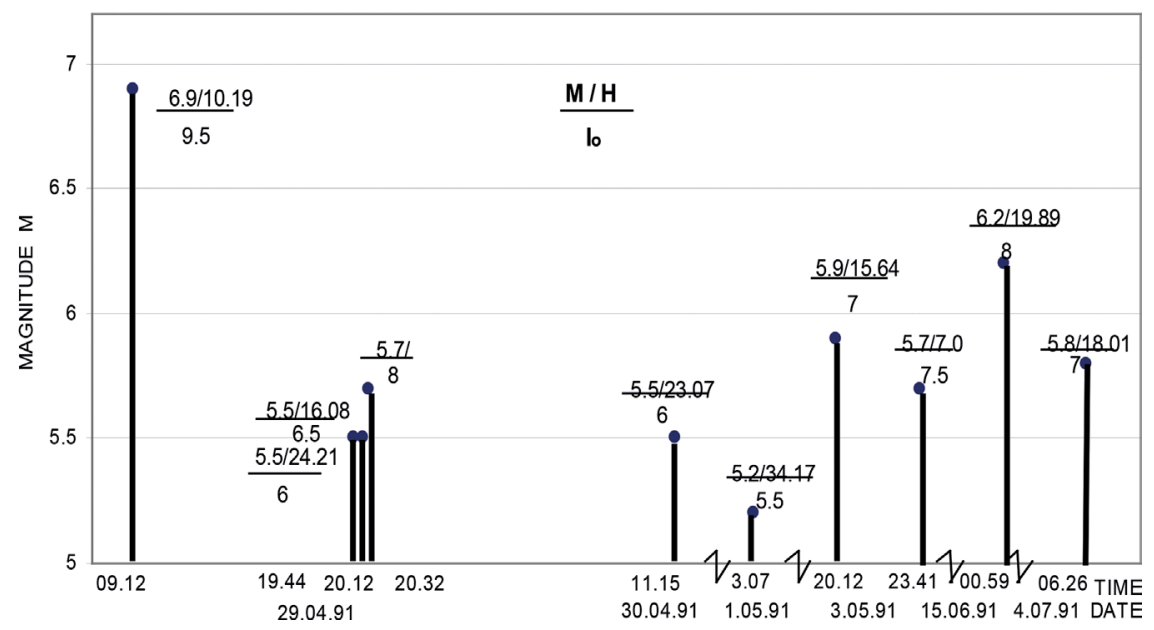

B

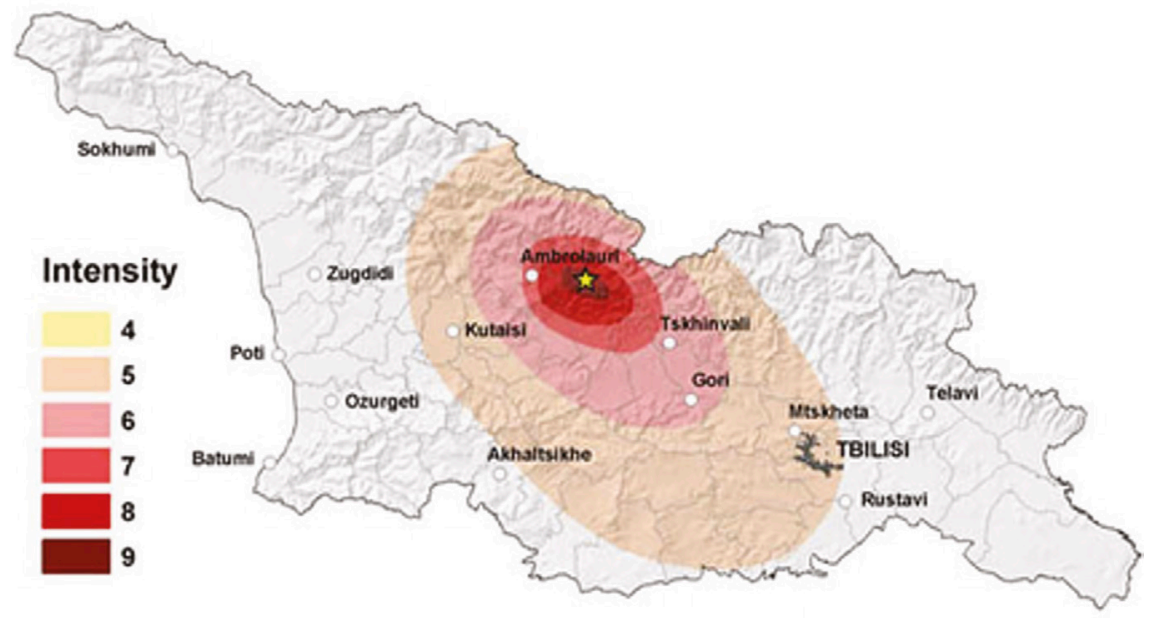

Figure 1: Seismic situation caused by the earthquake in Racha, Georgia, between April 29 and July 04, 1991, in the epicenter: (A) diagram: M - Richter magnitude; $\mathrm{H}$ - focus depth, km; $\mathrm{I}_{0}$ - intensity on MSK-64 scale. (B) calculated earthquake intensity map.

\section{NIKORTSMINDA TEMPLE}

The Nikortsminda temple was built in the 11th century (approximately in 1014). It has a cross-shaped structure with a drum and a brick dome (Fig. 2). The overall height of the structure is approximately $26 \mathrm{~m}$, the dome span is $6.4 \mathrm{~m}$, and its rise is $2.8 \mathrm{~m}$. The dome shell thickness is $0.6 \div 0.8 \mathrm{~m}$. The drum has three-layer walls with overall thickness $1.0 \div 1.5 \mathrm{~m}$, although weakened by windows. That shock caused cracking of the drum, and actually divided it into a group of vertically separated segments. In the dome, this generated a series 

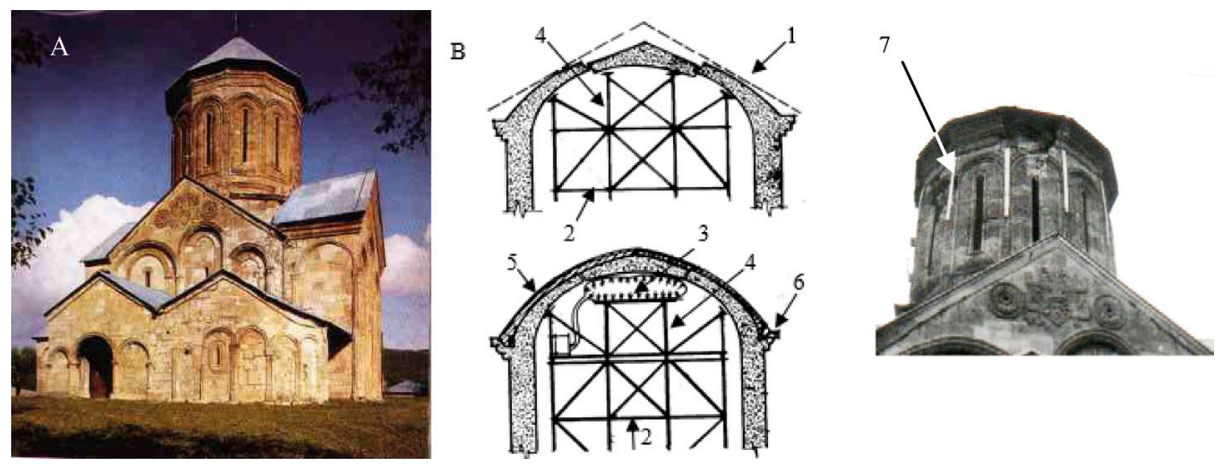

Figure 2: The temple in Nikortsminda. (A) General view; (B) damage of the dome and repair works: (1) dome; (2) scaffolding; (3) air pillow; (4) pillow support; (5) reinforced shell; (6) ring beam; (7) vertical timber boards.

of radial cracks and a closed-loop horizontal crack at the shell top. The central disk of the shell thus moved downwards by $60 \div 100 \mathrm{~mm}$ but was wedged by surrounding parts of the dome, and so did not collapse (Fig. 2B) [6].

Temporary conservation of the temple in Nikortsminda was carried out immediately after the main shock of the earthquake to prevent its collapse by possible aftershocks. The following measures were taken (Fig. 2A): external reinforcement of the dome ring beam, at the top of the drum (this included a ring bundle of diameter 10-mm steel wires); external reinforcing 'hoops', each consisting of several diameter 10-mm wires, mounted atop vertical timber boards (Fig. 2); internal scaffolding, designed to support damaged areas of the structure, including the drum and the dome. The temple performed at no further damage.

The permanent conservation project was completed 2 years later. Its major steps were as follows (Fig. 2B): construction of a steel belt around the ring beam of the dome; lifting of the central disk, weighing about $4 \mathrm{t}$, back to its original position (this was done using air pillows situated on the scaffolding, the gap between the disk and the surrounding shell, which remained after lifting, was filled with a lime-based mortar under pressure); filling of all radial cracks in the drum and in the dome by a lime-based mortar under pressure; construction of a reinforced concrete shell atop the dome (thickness: $80-90 \mathrm{~mm}, \mathrm{f}_{\mathrm{ck}}=30 \mathrm{MPa}$ ). As a result of these works, the dome was turned into a two-layer composite structure. Its original shape was restored and strengthened by an external reinforced concrete shell. Therefore, the internal appearance of the dome did not change, which allowed further restoration of ancient paintings.

\section{SYNAGOGUE IN ONI}

\subsection{Building of synagogue}

The synagogue was completed in 1895 . It is a rectangular symmetrical structure $(18.5 \times$ $14.9 \mathrm{~m}$ ) built of local stone, its maximum height being $15 \mathrm{~m}$. The dome, built of the same stone, has the $6.7 \mathrm{~m}$ span and the $3.0 \mathrm{~m}$ rise. It is situated in the centre of the structure, atop a drum, which is supported by arches. The ceiling in the corners is surmounted by vaults. The rectangular inner structure, on its four sides, has a flat ceiling on wooden beams. The beams, 
as the vaults, are situated atop outer walls and inner arches. The dome, drum, and vaults are built of the same stone. A cement-lime mortar was used for construction. The arches in the plan are located on mutually perpendicular directions. They are situated atop four stone columns symmetrically located inside the building and atop inner pilasters of the outer walls. The arches are tied at their bottom by steel rods with square cross section $(25 \times 25 \mathrm{~mm})$, for taking horizontal tensile forces. There is a stele (a stone plate covered with inscriptions) on the parapet of the frontal facade, and there are sculptural forms in all four corners of the building. The stele and sculptures are made of separate stones connected to each other by metal staples. Portico of the building is made of stone columns covered by stone vault. The columns are made of separate stones. Their bottoms are tied on the edges by metal tie bars, and rear columns of the portico are connected with the building by metal staples, located in the body of the vault and preventing free horizontal shift of the portico's structures. At present, this building has the status of the architectural and historical monument of Georgia.

\subsection{Damages of the buildings}

The earthquake caused substantial damage to the building, which did not collapse, however, due to its symmetrical structure, rigid walls, steel ties, and small arch spans. Overall views of the building after earthquake are presented in Fig. 3A. Cracks developed in actually all bearing elements, such as arches, shell, external walls, and in the drum (Figs 3 and 4). The crack opening in the arches was $5 \div 10 \mathrm{~mm}$. Many architectural elements and sculptures situated outside, at the facades, were severely damaged. Some of them collapsed, including fragments of walls (Fig. 3) [27].

\subsection{Conservation of the building}

A method for estimation of structural seismic resistance [28-30] was applied to this building [31]. The estimation done shows the most vulnerable (in the sense of seismic resistance) elements such as stone sculptures and a stele made of the local stone. It may be useful for
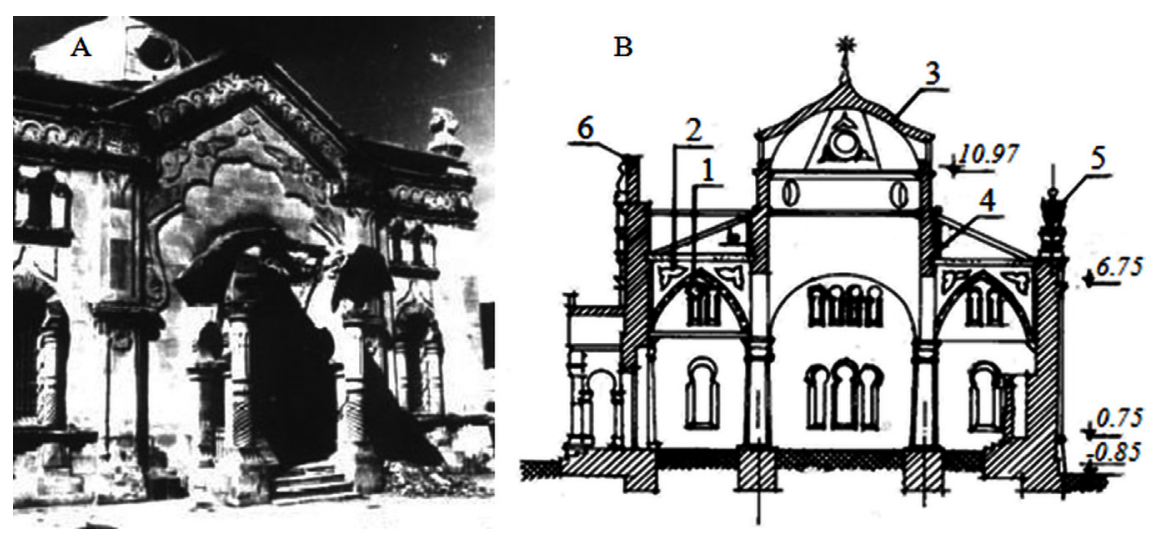

Figure 3: The synagogue in Oni: (A) view after the earthquake; (B) cross section: (1) arch; (2) ceiling; (3) dome; (4) drum; (5) collapsed sculpture; (6) collapsed facade element; (7) collapsed portico. 


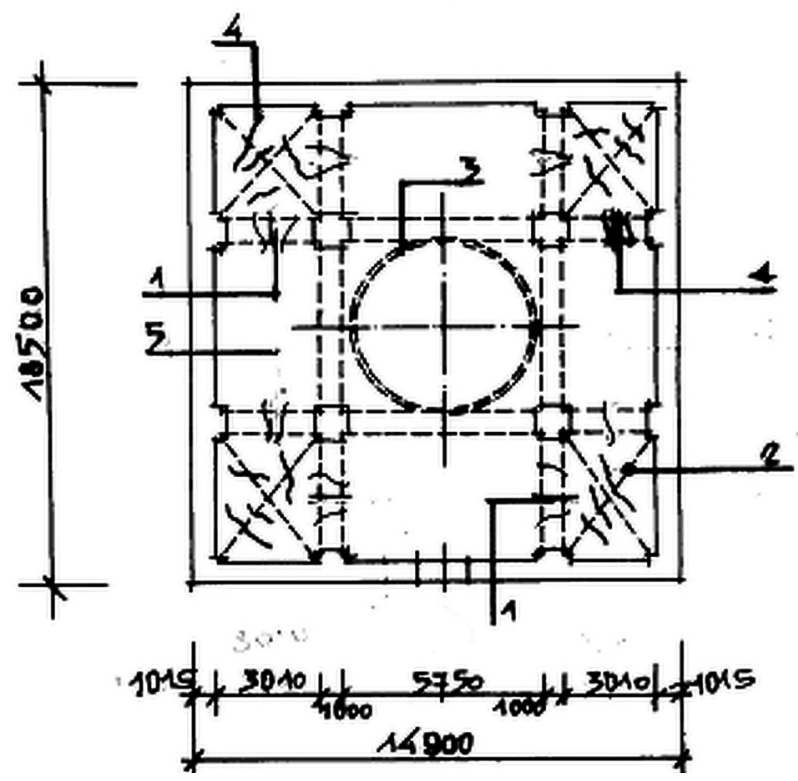

Figure 4: Plafond plan with the cracks shown (dimensions in mm): (1) arch; (2) surmounted vaults ceiling; (3) dome; (4) cracks; (5) wooden ceiling.
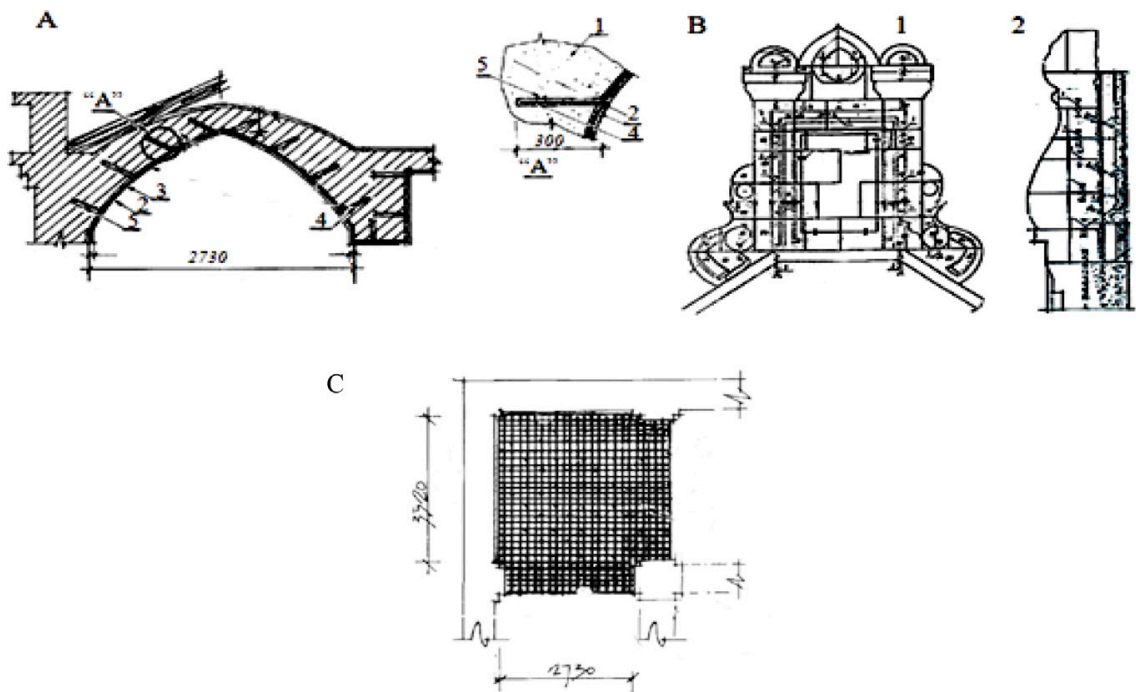

Figure 5: Details of strengthening (dimensions in $\mathrm{mm}$ ): (A and C) details of arches and vaults reinforcement: (1) arch; (2) reinforced plastering layer; (3) steel mesh; (4) drilling; (5) steel anchor. (B) Strengthening of the frontal stele: (1) frontal façade and (2) lateral façade. 
adopting the right strategy for developing the strengthening project [32]. Temporary conservation of the building after earthquake has not been carried out. Despite this, no further damage was done to the drum and the dome during the aftershock period. The retrofitting of these structures was completed 2 years later. Permanent conservation was primarily aimed at strengthening the bearing walls, arches, corner vaults, portico, stele, sculptures, drum, etc. (Fig. 5). Organization dealing with conservation of the Synagogue complex is the Georgian State Authority for Preservation of Monuments; authors of the conservation project are architect Prof. S. Bostanashvili, blessed be his memory, and structural engineer Dr. M. Danieli (Danielashvili). The project included the following major steps [18]: (a) removal of plaster, thorough cleaning, and filling of cracks with cement-lime mortar. Steel wedges were used to control complete filling of wide cracks ( $>6 \mathrm{~mm}$ ); (b) reinforced plastering of arch and shell surfaces in damaged areas. One layer of steel meshes $(150 \times 150 \mathrm{~mm})$ of 6 -mm diameter wires served as reinforcement. The meshes were tied to $10-\mathrm{mm}$ diameter steel anchors, each situated in a pre-drilled hole at a $30^{\circ}$ angle to the surface (Fig. 5B). Cement-lime mortar was applied $\left(\mathrm{f}_{\mathrm{ck}}=10 \mathrm{MPa}\right)$, so that the layer thickness was $40 \mathrm{~mm}$; (c) strengthening of the drum. Thin $10 \times 10 \mathrm{~mm}$ mesh of 1-mm diameter wires was used for external reinforcement. Cementlime mortar $\left(\mathrm{f}_{\mathrm{ck}}=10 \mathrm{MPa}\right)$ was applied to provide a 30-mm layer; (d) restoration of non-bearing external parts and architectural elements of the building using similar techniques. Details of strengthening are shown in Fig. 5. As a result of the strengthening, the capacity bearing of the above structural elements and seismic resistance became higher than they were before the earthquake.

\subsection{Some results of structural analysis}

Afterwards, to investigate the behavior of a building during an earthquake, a detailed analysis of seismic resistance was made using FEM [22]. Some results of structural analysis of the building under the action of seismic forces are presented in Fig. 6. When considering Fig. 5, we can see that the analyses given reflect the behavior of a building during an earthquake. In Fig. 6, we can clearly see how big are the displacements of the stele on the frontal wall. We can also see the concentration of the high-level stress at the base of the stele. Cracks in walls and corner vaults, destructions in the stele and shift of sculptures correspond to the results received. The results of such an analysis [28] given here correspond to the behavior of the building during the earthquake that makes it possible to recommend using FEM.

The view of the synagogue in Oni after the strengthening and restoration is shown in Fig. 7.

A

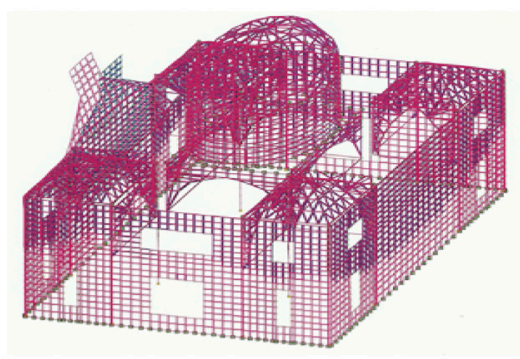

B

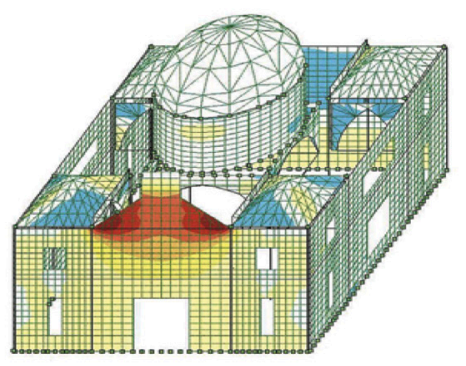

Figure 6: (A) Second mode shape in $\mathrm{Y}$ direction and (B) bending moments in $\mathrm{Y}$ direction. *Y direction is perpendicular to the frontal façade. 

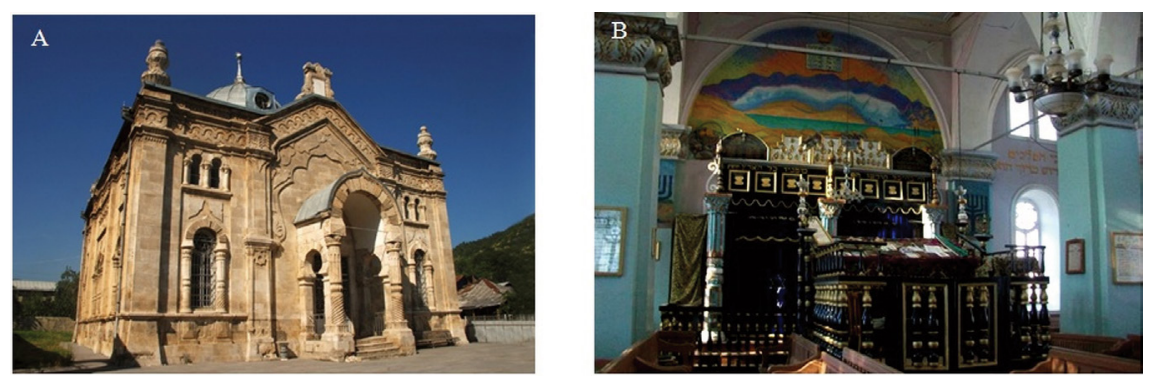

Figure 7: The synagogue in Oni after the strengthening and restoration: (A) general view and (B) interior.

\section{VERY SHALLOV THIN-WALLED REINFORCED CONCRETE SHELLS}

\subsection{Designed structure}

Beginning with 1950, very shallow thin-walled reinforced concrete shells of floors and coverage in a square or rectangular plane have been widely employed in civil engineering in the Republic of Georgia [33]. The shells are embedded in an octagonal flat contour (Fig. 8). When the plane is square, the shell of revolution is embedded in the octagonal contour (the surface shell of revolution is spherical or cone-shaped). In the area adjacent to the contoured areas, the shell of revolution merges with the plate. Shells in rectangular plane in the central part have cylindrical insertion while at the edges have spherical surface .The shell size in plane is $8-20 \mathrm{~m}$, the rise $\mathrm{f}=(1 / 30-1 / 40) \mathrm{a}$, where a is the length of the shell side and shell thickness $\mathrm{h}=6-8 \mathrm{~cm}$. The strength of concrete was designed to be $110-150 \mathrm{~kg} / \mathrm{cm}^{2}$. Design complete project loading is $600 \mathrm{~kg} / \mathrm{m}^{2}$.

The following factors constitute the main defects of the design: (a) welding did not provide sufficient continuity of the tensed reinforcement of contour beams; (b) initially accepted grade of concrete (11 MPa) was too low; subsequently, it was improved to be $15 \mathrm{MPa}$; (c) shells were too sloping ( $f=1 / 30 a)$; (d) the rise/thickness ratio was often $f / h \leq 6$. The last two factors are very important. They indicate that such shells can change their form as a result of deflection, which makes it expedient to design shells on the basis of non-linear theories. From the static point of view, non-linear factors deteriorate the work of the shell constructions. Therefore, Norms [30] recommend refusing the construction design of shells that require using a non-linear theory. The above defects - the main of them being big slope, low grade of concrete, and insufficient thickness $(\mathrm{h}=6 \mathrm{~cm})$ - resulted, in some cases, in collapsing such shells and putting them out of operation.

\subsection{Shell in rectangular plane}

In Khareli settlement (Republic of Georgia), there was the loss of stability and deformation of a monolith reinforced-concrete shell in a public building (Fig. 8). The shell sizes in plane are (net): $8.4 \times 10.2 \mathrm{~m}$, thickness: $8-10 \mathrm{~cm}$, designed rise: $50 \mathrm{~cm}$, designed strength of concrete: $11 \mathrm{MPa}$. The shell was built in 1960-1962. After 15-year operation, the stability was lost and the shell deformed due to the low grade of concrete under conditions of big slope (Fig. 9). 


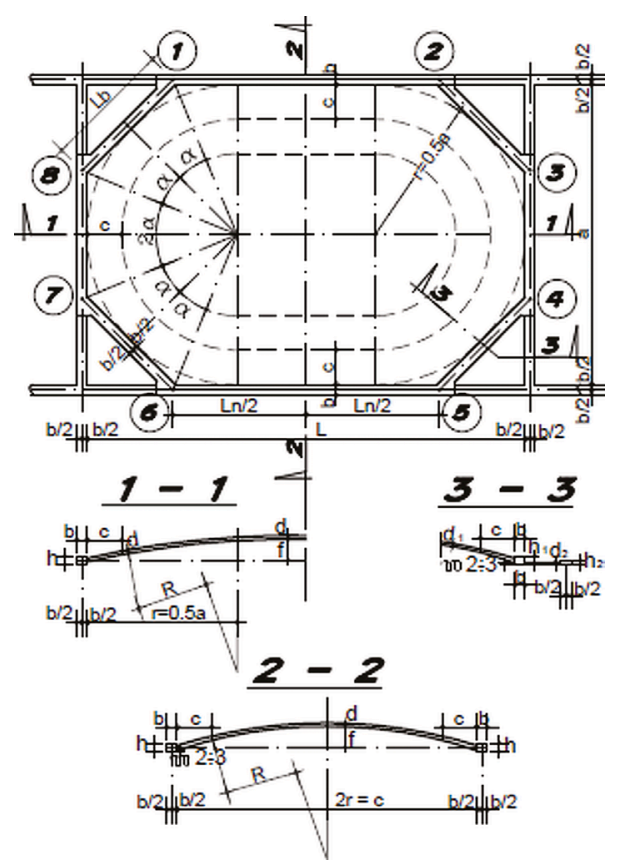

Figure 8: Ceiling shells with small rise.

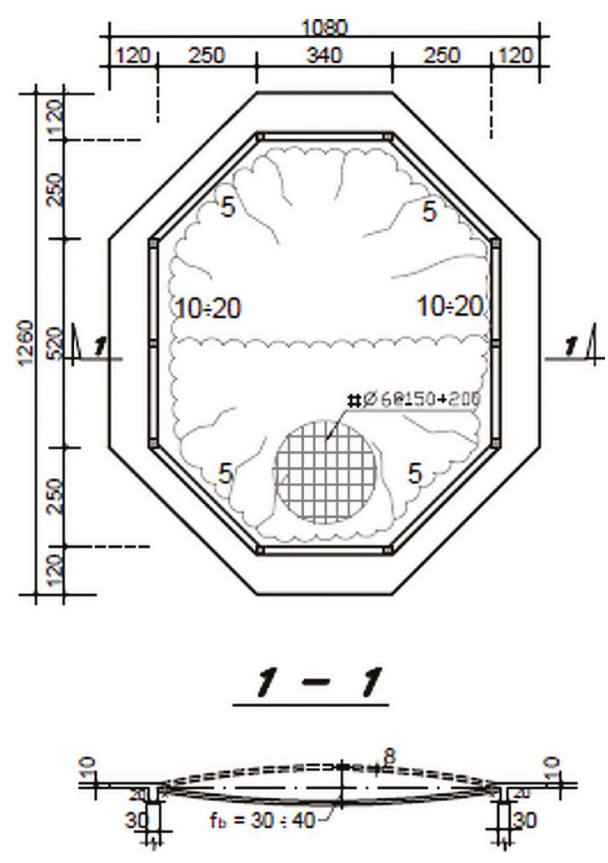

Figure 9: Rectangular shell after stability loss (dimensions in $\mathrm{cm}$ ) together with scheme of cracks arrangement (width of cracks: $\mathrm{mm}$ ). 
The inspection on the spot showed that the concrete was very light pumice, the actual compression strength determined using standard Hammer was 5-6 MPa, the body was reinforced with a single reinforcing fabric with bar diameter being $6 \mathrm{~mm}$ and pitch $15-20 \mathrm{~cm}$. The deformation of the shell was as follows: there was a deflection on one side, and there were ring and radial cracks (Fig. 9). The actual total load did not exceed 250 $\mathrm{kg} / \mathrm{m}^{2}$. Using FEM within STRAP (Structural Analysis Program) according to the linear theory, with the load being $250 \mathrm{~kg} / \mathrm{m}^{2}$ and the concrete strength being $10 \mathrm{MPa}$, deflections in the middle of the shell are $6 \mathrm{~mm}(\mathrm{w} / \mathrm{h}=6 / 80=1 / 13 ; \mathrm{w} / \mathrm{a}=6 / 8400=1 / 1400)$, compression strength $1.75 \mathrm{MPa}$, and tensile force in the near-contoured area $-6.8 \mathrm{t} / \mathrm{m}$. The existing reinforcement is capable of taking up load of 4-5 t/m (Steel rods with a diameter of $6 \mathrm{~mm}$ were placed at every $15-20 \mathrm{~cm}$ along the ring line). This accounts for significant cracks on the shell surface in the near-contoured area. Figure 10 shows distribution of stress $S\left(t / \mathrm{m}^{2}\right)$ in the shell body with the load being $580 \mathrm{~kg} / \mathrm{m}^{2}$. The analysis was made by Ioram Varon, the student of the Ariel University (now an engineer).

According to the stability analysis formulas [30], with due account of actual data, the intensity of acceptable load was determined to be $\mathrm{q}=60 \mathrm{~kg} / \mathrm{m}^{2}<<250 \mathrm{~kg} / \mathrm{m}^{2}$. As a result of the loss of stability, the shell got turned out, the sag was $30-40 \mathrm{~cm}$, and strain crack appeared. Due to sufficiently good bar anchorage of the shell in the contour beam, reinforcement bars of the shell got hanged on contours beams; with the anchorage bars being 30-cm long and reinforcement adhesion with concrete being very low $\left(f_{b d}=0.3 \mathrm{MPa}\right)$, the total strength of adhesion of reinforcement bars is $30 \mathrm{t}$ and the total weight of the sagged shell did not exceed $20.0 \mathrm{t}$.

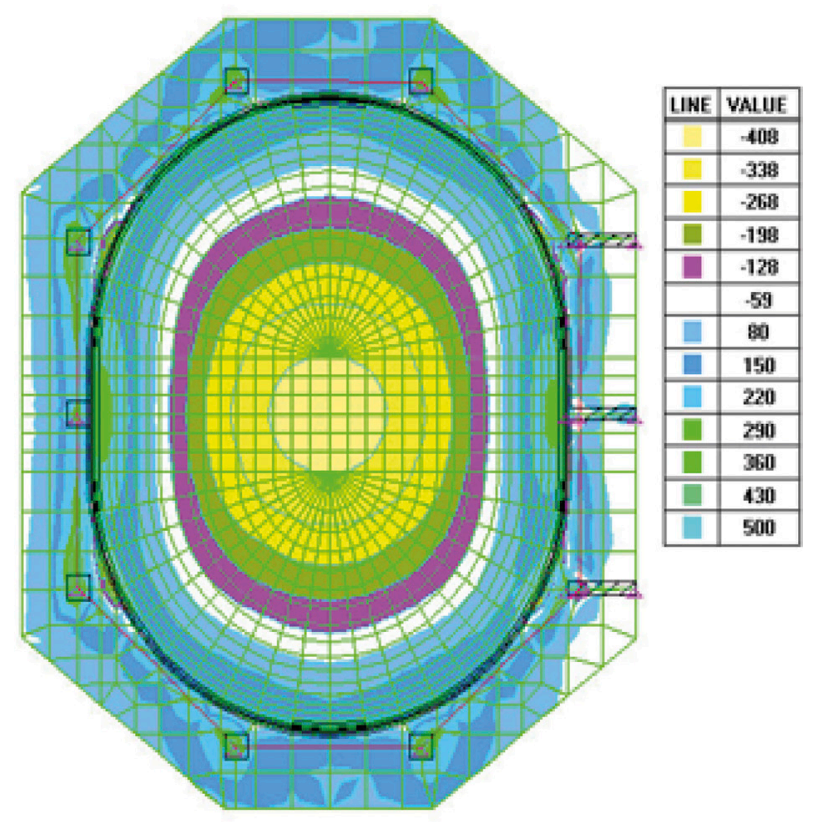

Figure 10: Normal stress in $\mathrm{X}$ direction $\left(\mathrm{t} / \mathrm{m}^{2}\right)$. 


\subsection{Shell in square plane}

In one of the Civil buildings in Tbilisi (1952), there were floors constructed in a square plane with the dimensions of $10 \times 10 \mathrm{~m}$ of very shallow reinforced concrete shells of the type being considered (Fig. 11A) [33]. The surface embedded in the octagonal shells of revolution is cone-like, rising within the rate of $\mathrm{f} / \mathrm{a}=(1 / 30-1 / 40)$. The actual concrete brand is $120-150$ $\mathrm{kg} / \mathrm{cm}^{2}$ and the thickness of the shell is $6-8 \mathrm{~cm}$. Continuous load-dead load of the shell and floor structure was equal to $560 \mathrm{~kg} / \mathrm{m}^{2}$, and the temporary load was $200-300 \mathrm{~kg} / \mathrm{m}^{2}$. After 20 years of operation, the surface of the shell at the edges developed local cavities and cracks. The scheme of cracking is given in Fig. 11B. It corresponds theoretically to the well-motivated single-parameter fracture scheme of shells of revolutions [23,24]. Due to great deformations, the temporary load was removed (a library and reading hall were placed over a shell) and the operation of shells was suspended. The designed carrying capacity of shells,

A

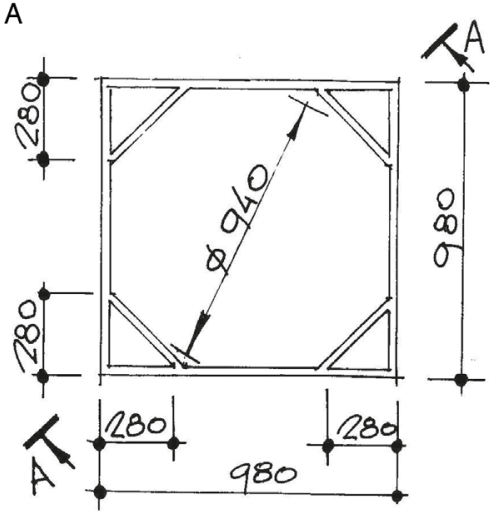

B

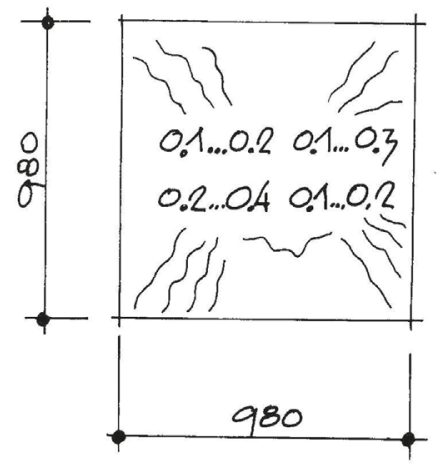

$\underline{A-A}$

C

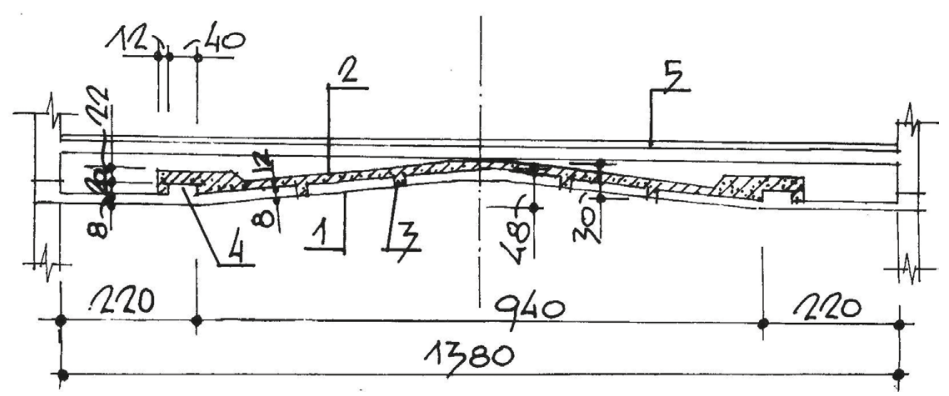

Figure 11: Very shallow reinforced concrete shell (dimensions in $\mathrm{cm}$ ): (A) scheme of shell plane; (B) scheme of cracks arrangement on the lower surface of shell (width of cracks: mm); (C) scheme of strengthening shell: (1) old shell; (2) new shell; (3) reinforced concrete shell key; (4) contour beam; (5) construction of floor. 
defined using actual geometry parameters reinforcement and concrete strength, was as follows [33]: according to the theory of limit equilibrium in relations [24] $\mathrm{q}=520 \mathrm{~kg} / \mathrm{m}^{2}$; according to the theory of limit equilibrium considering geometric nonlinearity [25], $q=490$ $\mathrm{kg} / \mathrm{m}^{2}$; according to the membrane theory of shells [34], $\mathrm{q}=400 \mathrm{~kg} / \mathrm{m}^{2}$ (proceeding from a condition of strength of the reinforcement supporting ring); according to stability (long-term strength) [34] $-160 \mathrm{~kg} / \mathrm{m}^{2}$. Calculation displacement in the centre of shell is $\mathrm{w}=15.06 \mathrm{~mm}$ $(\mathrm{w} / \mathrm{h}=1.5 / 6=1 / 4, \mathrm{w} / 2 \mathrm{R}=1.5 / 2 \times 470=1 / 625$, where $\mathrm{R}$ is the radius of a circle embedded in the octagon). These data show that the strength of the shell is not sufficient, and a great number of deformations are appropriate. As for the value determined proceeding from the stability condition, it then has considerable margin. This accounts for the fact that long coefficient of stability is in conformity with [33]. To restore operational qualities of the shells being considered, they were strengthened (Fig. 11C).

The floor structure was completely removed from the shells. On a peeled surface of the existing shell, there was mounted a new monolithic reinforced concrete shell with the thickness of $12 \mathrm{~cm}$, rising $30 \mathrm{~cm}(\mathrm{f} / \mathrm{L}=30 / 9400=1 / 30)$, and concrete strength of $300 \mathrm{~kg} / \mathrm{cm}^{2}$. New and old shells were joined using a key in which reinforcing bars of the indicated shells were connected. In addition to these measures, contour beams were also reinforced by building up the height from the top and adding new reinforcing bars. Design load (total dead load and temporary load) of a new shell defined by the theory of limit equilibrium is $q=1400 \mathrm{~kg} / \mathrm{m}^{2}$, by the membrane theory of shells, $1100 \mathrm{~kg} / \mathrm{m}^{2}$, by stability (long-term strength) [34] of a separate new shell $(\mathrm{h}=12 \mathrm{~cm}), 400 \mathrm{~kg} / \mathrm{m}^{2}$, or a united one $(\mathrm{h}=20 \mathrm{~cm}), 1200 \mathrm{~kg} / \mathrm{m}^{2}$. Strengthening of three shells was carried out in 1993; they have been successfully used since then. The method of strengthening reinforced concrete sloping shells described in this paragraph was assumed as a basis of the proposed method of strengthening ancient stone domes described in chapter of this article.

\section{CONSERVATION PROJECTS FOR THE STONE DOMES}

\subsection{The heritage building in Akhaltsikhe}

The building of the former mosque in the town of Akhaltsikhe (Fig. 12A) was constructed in 1758. The historical view without roof of the building is shown in Fig. 12B. The inner

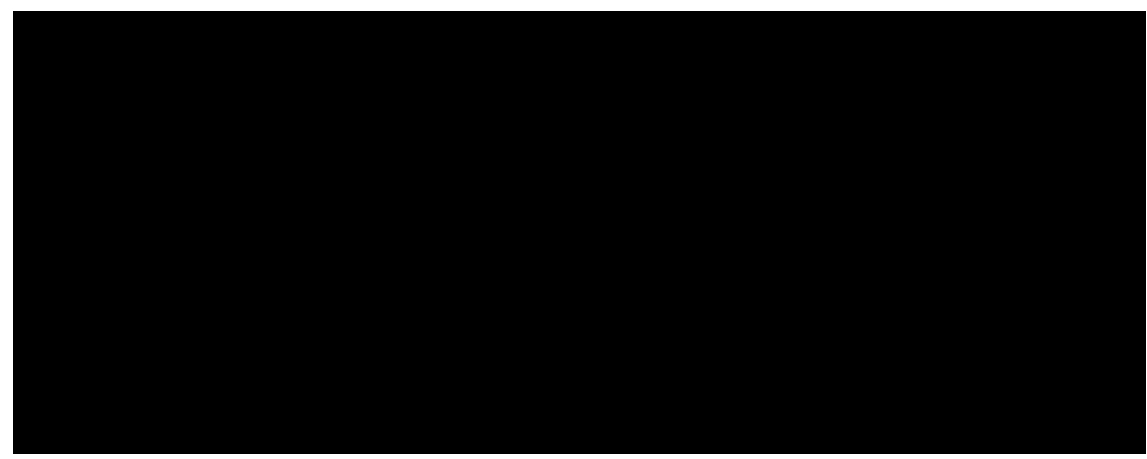

Figure 12: Dome (former mosque) in Akhaltsikhe: (A) view of a modern picture and (B) historical view without roof. 

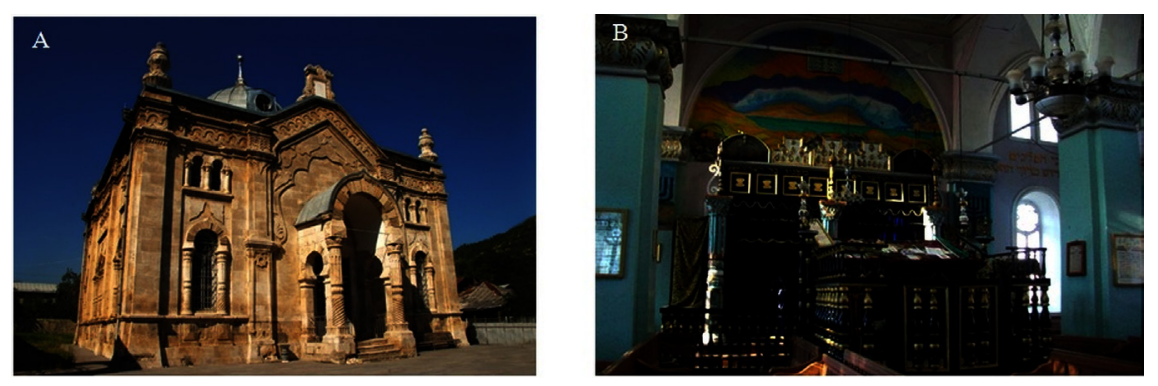

Figure 13: Inner surface: (A and B) cracks of dome in Akhaltsikhe: (A) picture and (B) scheme.

diameter of the supporting contour of the dome is about $16 \mathrm{~m}$; inner height (rise) is about 8 $\mathrm{m}$, and the thickness of the walls is $0.6-0.8 \mathrm{~m}$. The dome was constructed from thin clay bricks with the dimensions of $24 \times 24 \times 4 \mathrm{~cm}$, on a lime-clay mortar.

The brick edges stand out horizontally in steps on the upper surface of the dome (Fig. 12B). The dome has typical cracks originating from the supporting zone in the meridian direction and opening crack width on the lower surface of 1.5-2.0 cm (Fig. 13A and B); additional weak zones of a dome are created by window openings. There is a clear need for dome conservation and strengthening, taking into account the history and architecture of the important building, the existence of developed cracks, and the need to save it from seismic loads during possible severe earthquakes without significant damage.

\subsection{Strengthening of the structure stone domes}

An original strengthening structure is proposed hereby [35] (Fig. 14), according to proposed design for strengthening the stone dome of Akhaltsikhe. It is proposed to carry out the strengthening of the existing dome from its outer surface to preserve the appearance of the interior authentic surface of the dome; for example, the stone dome of Akhaltsikhe with its stone masonry containing cracks in the lower part (Fig. 13B).

Execution of the construction work in such a manner has some advantages: the strengthening structure is located under the roof covering and the stone dome is used as scaffolding for the structure. The strengthening structure consists of a thin-walled reinforced concrete shell, cast on top of the existing stone dome, and a supporting ring at its bottom (Fig. 14). Thickness of 6-12 cm could be recommended for the reinforced concrete shell in most cases of stone dome spans. The reinforced concrete supporting ring is placed in a groove engraved into the stone. The necessary connection to provide interaction of the stone dome and the reinforced concrete shell is achieved by means of reinforced concrete connection elements. These elements (such as pins), in the shape of a truncated pyramid or cone (with the large base in the stone dome), protrude from the reinforced concrete shell and penetrate into the stone dome, distributed through the entire dome surface. An additional linkage is the adherence force between the neighboring surfaces of the stone dome and reinforced concrete shell. The upper surface of the stone dome may be roughened to increase this force. In certain cases, this adherence force may become the principal way of connection.

Thus, the interconnected stone-reinforced concrete shell is achieved. The application of the proposed method enables strengthening a stone dome through practically all its thickness, 


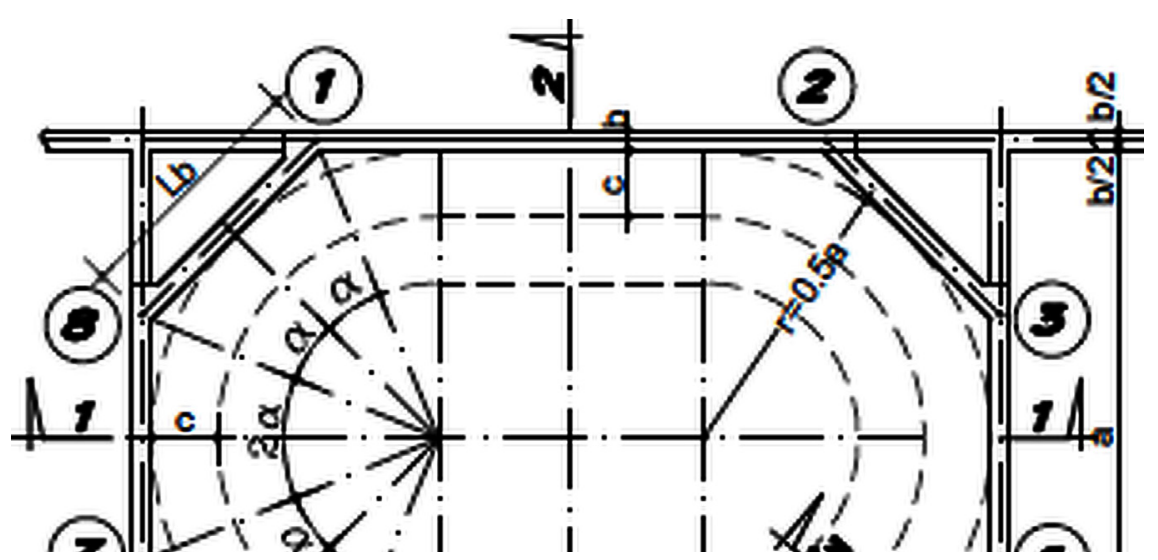

Figure 14: Dome in Akhaltsikhe strengthening construction (dimensions in $\mathrm{cm}$ ): (1) stone dome; (2) reinforced concrete shells; (3) supporting ring; and (4) connection elements.

which is important, as seismic action could be from a non-predictable direction. The stresses in a stone dome may be decreased significantly as a result of strengthening by the proposed method; it could significantly raise the earthquake resistance of a stone dome; the thrust forces are perceived by the reinforced concrete ring and so the dome supporting structures are relieved of effects from horizontal forces. An actual example of a similar strengthening for a reinforced concrete shell of 10-m diameter with a very moderate slope is given in Section 5.3. To study the stress-strain state characteristics of the strengthened structure, as well as to estimate the efficiency of the proposed strengthening method, a series of analyses were executed by FEM [35]. The obtained results show the efficiency of the proposed strengthening method.

\section{EXPERIENCE}

On September 8, 2009, there was an earthquake in northern Georgia. The magnitude in the epicenter of the earthquake was 6.2. A total of 1,400 houses were damaged or destroyed. The epicenter was $12 \mathrm{~km}$ from Oni, which was the most damaged location (Fig. 15). The distance from the epicenter to Nikortsminda is about $40-45 \mathrm{~km}$. The buildings of the synagogue in Oni and the temple in Nikortsminda survived this earthquake without any substantial damage caused. It proves the effectiveness of the strengthening and rehabilitation works in these buildings performed by us.

\section{CONCLUSIONS}

1. As a result of the earthquake on April 29, 1991, the synagogue in Oni and the temple in Nikortsminda were damaged. Some structures of the synagogue in Oni, mainly console structures, collapsed.

2. Regarding conservation of historical buildings, one can distinguish between temporary and permanent conservation. Temporary conservation of the temple in Nikortsminda was carried out immediately after the main shock of the earthquake to prevent its collapse by possible aftershocks. Temporary conservation, if done in time, can prevent the collapse 


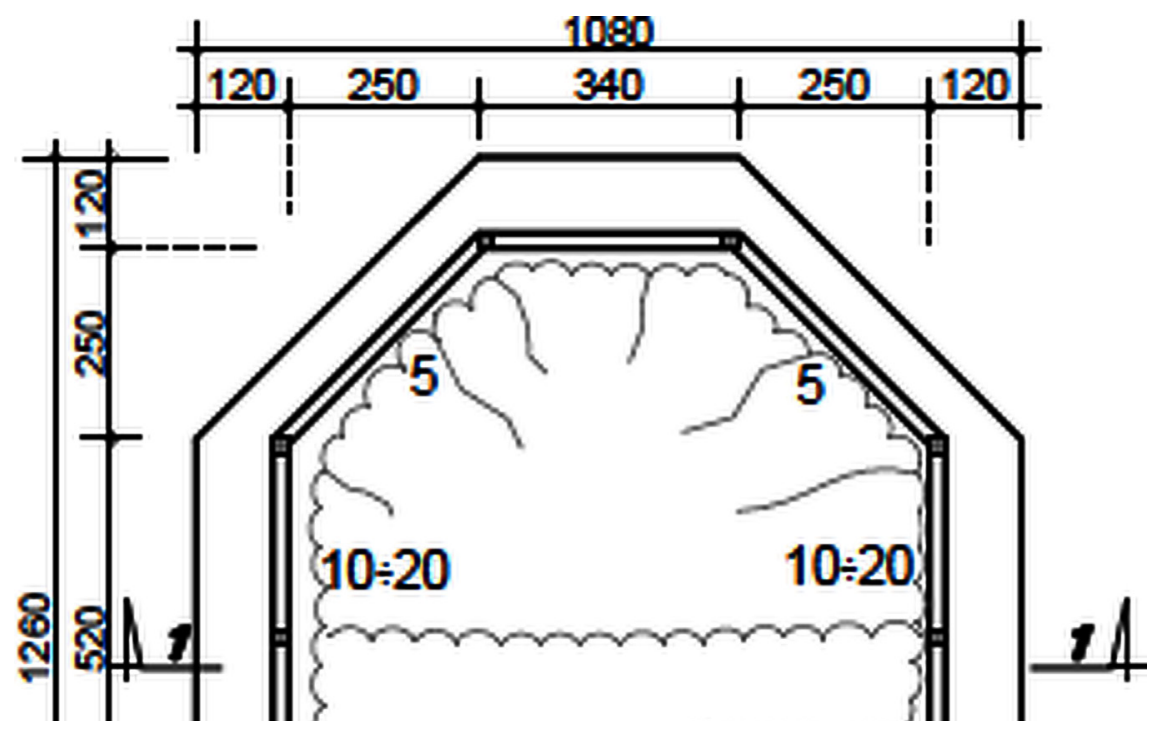

Figure 15: Seismic situation caused by the 2009 earthquake in Georgia.

of damaged structures and thus make their subsequent conservation (strengthening) and restoration possible.

3. The retrofitting of these structures was completed 2 years later. The estimation of the seismic resistance and strengthening was done using the method of estimation of structural seismic resistance of buildings. Afterwards, to investigate the behavior of a building during an earthquake, a detailed analysis of seismic resistance of the synagogue in Oni was made using FEM. The results of such an analysis given here correspond to the behavior of the building during the earthquake closely enough, which makes it possible to recommend successfully using FEM.

4. The temple in Nikortsminda and the synagogue in Oni after the strengthening and restoration survived the Richter magnitude 6.2 earthquake in this region on September 8,2009 , without any substantial damage caused. Methods and techniques offered and applied for retrofitting the synagogue in Oni and the temple in Nikortsminda may be recommended for the strengthening and conservation of other historic structures.

5. Causes of significant deformations of thin and very sloping shells of octagon contour are discussed; loss of stability and deformation of one shell of this type in rectangle plane are considered. An example is given of strengthening and securing safety of the shells of this type in square plane.

6. The original method of strengthening reinforced concrete sloping shells described in this article was assumed as a basis of the proposed method of strengthening ancient stone domes.

7. An original Stone Dome strengthening structure is proposed. It consists of a new thinwalled reinforced concrete shell with a supporting ring, cast on top of the existing stone dome. It makes it possible to preserve the existing ancient appearance of the inner surface of the dome. The connection between the old stone dome and a new reinforced concrete shell is achieved by using special reinforced concrete connecting elements and by 
adhesion of the neighboring surfaces. Thus, an interconnected stone-reinforced concrete composite structure is created. As a result, the earthquake resistance of the stone domes increases significantly.

8. The Akhaltsikhe stone domes can serve as an example of the efficiency of the proposed method as is shown by numerical analysis using FEM. Besides, design principles applied in strengthening projects for the dome in Akhaltsikhe can provide substantial contribution to successful conservation of other stone domes, along with the increase of their earthquake resistance.

\section{ACKNOWLEDGEMENTS}

The authors are thankful to Dr. G. Sirotin (Ariel University, Ariel, Israel) for his assistance in preparing this article for publication and to engineer Ioram Varon for providing Fig. 10.

\section{REFERENCES}

[1] Krautheimer, R. \& Ćurčić, S., Early Christian and Byzantine architecture, Penguin Books Ltd: Harmondsworth, Middlesex, England, 1986.

[2] Paret, T., Freeman, S., Searer, G., Hachem, M. \& Gilmarin, U., Seismic evaluation and strengthening of an historic synagogue using traditional and innovative methods and materials. Proc. $1^{\text {st }}$ European Conference on Earthquake Engineering and Seismology, Geneva, Switzerland, (SD-R) Paper No. 701, 2006.

[3] Repair and strengthening of historical monuments and buildings in urban nuclei. Building construction under seismic conditions in the Balkan region. NDP/UNIDO Project Rep/79/015, Vienna, 1984.

[4] Sesigur, H., Celik, O.C., Cili, F., Repair and strengthening of ancient structures. Proc. $1^{\text {st }}$ European Conference on Earthquake Engineering and Seismology, Geneva, Switzerland, Paper No.1387 (SD-R), 2006.

[5] Rabin, I., Structural Analysis of Historic Buildings: Restoration, Preservation and Adaptive Application for Architects and Engineers, Wiley \& Sons: New-York, 2000.

[6] Danieli (Danielashvili), M., Gabrichidze, G., Goldman, A. \& Sulaberidse, O., Experience in restoration and strengthening of stone made ancient domes in seismic regions. Proc. 7th US NCEE, Boston, MA, USA, Vol II: pp. 1167-1175, 2002.

[7] Jasie ko, J. \& Bednarz, Ł.J., Strengthening of historic masonry vaults. Proceedings of the Eighth International Masonry Conference, Dresden, 4-7 July 2010, Vol. 3, eds. Wolfram Jäger, Barry Haseltine, \& Anton Fried, Technische Universität Dresden: Dresden, pp. 2131-2140, 2010.

[8] Jasie ko, J., Bednarz, Ł. \& Nowak, T. The effectiveness of strengthening historic brick vaults by contemporary methods. PROHITECH 09. Proc. of the International Conference on Protection of Historical Buildings, Rome, Italy, 21-24 June 2009, Vol. 2, ed. F. M. Mazzolani, CRC Press, pp. 1299-1304, 2009.

[9] Protection of Historical Buildings, PROHITECH 09, Proc. of the International Conference on Protection of Historical Buildings, Rome, Italy, 21-24 June 2009, Vols 1 \& 2, ed. Federico M. Mazzolani, CRC Press, 2009.

[10] Penelis, G., Karavesiroglou, M., Stylianidis, K. \& Leontaridis, D., The Rotunda of Theassaloniki: seismic behavior of Roman and Byzantine structures, Hagia Sophia from the Age of Justinian to the Present, ed. R. Mark \& A.Ş. Calmak, Cambridge University Press, pp. 132-157, 1992. 
[11] Poland, C.D. \& Reis, E.M., The repair and strengthening of historic Stanford Memorial Church, Tenth World Conference, Balkema: Rotterdam, pp. 5341-5346, 1992.

[12] Gabrilovich, P. \& Richard, P., Methodology for strengthening and repair of earthquake damaged monuments in Pagan, Burma, Proc. of Eight World Conference on Earthq. Engin, San Francisco, USA, Vol. 1, pp. 609-616, 1984.

[13] Ziyaeifar, M., Meshki, H. \& Rajaei, M., Rehabilitation of historical buildings subjected to seismic hazards, a methodology, 13th World Conference on Earthquake Engineering, Vancouver, BC, Canada, Paper No. 1598 (SD-R), 2004.

[14] Bednarz, Ł., Jasieńko, J., Rutkowski, M. \& Nowak, T., Strengthening and long-term monitoring of the structure of an historical church presbytery. Engineering Structures, 81, pp. 62-75, 2014. doi: http://dx.doi.org/10.1016/j.engstruct.2014.09.028

[15] Pizzetti, G. \& Fea, G., Restoration and strengthening of the elliptical dome of Vicoforte Sanctuary. Proc. of the IASS-MSU Int. Symposium, Istanbul, pp. 289-308, 1988.

[16] Sofronie, R.A., Crisan, R. \& Toanchina, M., Retrofitting the masonry of cultural heritage. Fifth National Conference on Earthquake Engineering, Istanbul, Turkey, Paper No. AE-013 (SD-R), 2003.

[17] Danieli, M. \& Bloch, J., Rehabilitation of the religious heritage in seismic regions: principle and practice. Protection of historical buildings. PROHITECH 09. Proc. of the International Conference on Protection of Historical Buildings, Rome, Italy, 21-24 June 2009, Vol. 1, ed. Federico M. Mazzolani, CRC Press, pp. 125-130, 2009.

[18] Danieli, M. \& Bloch, J. Principle, practice and experience of rehabilitation of the historical buildings in seismic regions. Proceedings of the 15th World Conference on Earthquake Engineering (15WCEE), 24-28 September 2012, Lisbon, Portugal, pp. 1-9, Paper No. 392.

[19] Jasieńko, J., Di Tommaso, A. \& Bednarz, Ł., Experimental investigations into collapse of masonry arches reinforced using different compatible technologies. W: Meccanica delle strutture in muratura rinforzate con compositi: modellazione, sperimentazione, progetto, controllo: Atti del 3 Convegno Nazionale, Venezia, 22-24 April 2009, Bologna, Pitagora, pp. 316-324, 2009.

[20] Krstevska, 1., Tashkov, L.J.,Gramatikov, K., Mazozolani, F.M. \& Landofo, R. Shaking table test of Mustafa Pasha Mosque model in reduced scale. PROHITECH 09. Proc. of the International Conference on Protection of Historical Buildings, Rome, Italy, 21-24 June 2009, Vol. 2, ed. Federico M. Mazzolani, CRC Press, pp. 1633-1639, 2009.

[21] Bednarz, Ł., Górski, A., Jasieńko, J. \& Rusiński, E., Simulations and analyses of arched brick structures. Automation in Construction, 20(7), pp. 741-754, 2011. doi: http:// dx.doi.org/10.1016/j.autcon.2011.01.005

[22] Danieli, M. \& Aronchik, A., Case study: the strengthening and seismic safety of the Oni synagogue in Georgia. Proc. of the 13th International Conference on Structures under Shock and Impact (SUSI XIII), ed. C.A. Brebbia, WIT Press, pp. 456-466, 2014.

[23] Akhvlediani, N., Design of reinforced concrete domes by the method of limit equilibrium, Studies of the Theory of Structures Issue 10, Gosstroiizdat: Moscow, pp. 127-132, 1961. doi: http://dx.doi.org/10.2495/susi140391

[24] Akhvlediani, N. \& Danielasvili, M., Limit analysis of reinforced concrete shells, Archiwum Inz. Ladowey, 36(3), pp. 187-205, 1990.

[25] Shugaev, V., Engineering Methods in Nonlinear Theory of Limit Equilibrium of Shells, Gotik: Moscow, 2002. 
[26] Gabrichidze, G. (ed.), Engineering Analysis of the Racha Earthquake Consequences in Georgia 1991, Metsniereba: Tbilisi, GA, 1996.

[27] Danielashvili, M., Synagogue in Oni. Engineering Analysis of the Racha Earthquake Consequences in Georgia 1991, Metsniereba: Tbilisi, GA, 1996.

[28] Sekhniashvili, E.A., Danielasvili, M.A. \& Zhorzholadze, T.A., Instruction for Investigating the Technical Conditions and Seismic Stability of Civil and Public Buildings in Georgia. Ministry of Architecture and Building, Academy of Sciences of Georgia: Tbilisi, GA, 1992 (in Georgian).

[29] Danielasvili, M.A. \& Tchatchava, T.N., A method for quantitative estimation of the earthquake resistance of buildings. Earthquake Engineering, 1, pp. 14-16, 1999 (in Russian).

[30] Danieli, M. \& Bloch, J., Evaluation of Earthquake Resistance of Existing Reinforced Concrete Buildings, Ariel University: Ariel, pp. 192, 2014.

[31] Danieli (Danielashvili), M. \& Bloch, J., Evaluation of earthquake resistance and the strengthening of buildings damaged by earthquake. Proc. 1st European Conference on Earthquake Engineering and Seismology, Geneva, Switzerland, Paper No. 673 (SD-R), 2006.

[32] Levin, M.S. \& Danieli, M.A., Hierarchical decision making framework for evaluation and improvement of composite systems (example for building), Informatica, 16(2), pp. 213-240, 2005.

[33] Danielashvili, M., Gabrichidze, G., Melashvili, Y. \& Sulaberidze O., Study of some reinforced and metal spatial structures in seismic regions of Georgia. Proc ICSS-98, Vol. 1, Moscow, pp. 396-403, 1998.

[34] Instruction manual on design of the reinforced concrete space coverings and floor structures, (in Russian). Stroiizdat: Moscow, 1979.

[35] Danieli, M., Aronchik, A. \& Bloch, J., An original method for strengthening ancient stone domes in seismic regions and solving corresponding problems of stress-strain state analysis. IJRET: International Journal of Research in Engineering and Technology, 3(10), pp. 1-15, 2014, available http://www.ijret.org. doi: http://dx.doi.org/10.15623/ ijret.2014.0310001 